\title{
QUALITY STATE OF LIPOPROTEINS IN PATHOLOGIES WITH DIFFERENT GENESIS
}

\section{Vasylchenko V. S., Kuchmenko O. B.}

\section{INTRODUCTION}

Homeostasis is ensured by the consistency of multifunctional reactions of the human body. Their important component is the metabolism of lipids and lipoproteins. The particles of low and high-density, provide afferent and efferent transport of cholesterol ${ }^{1}$. Cholesterol plays numerous functions in the body of chordates, the most important of which are structural, regulatory and numerous others ${ }^{2}$.

The involvement of cholesterol in cardiovascular and immune systems had been studied the best ${ }^{3}$. Beginning in 1948 , with the initiation of largescale research in the city of Framingham, it was considered one of the main indicators of the development of cardiometabolic diseases. During the nearly seventy-year period, the study provided significant insights into the spread and risks of cardiovascular disease ${ }^{4}$.

The first large-scale Framingham study had shifted focus from treatment interventions to preventative ones and the increase in pressure, along with such risk factors as obesity, smoking, the elevation of total cholesterol and haemoglobin, have become markers of the possible development of cardiometabolic syndromes. Scientists began to pay attention to other indicators that reflect the quality of lipid metabolism. In particular, the amount of low-density lipoprotein cholesterol, changes in the level of which are associated with the development of cardiovascular diseases and the qualitative state of high-density lipoproteins 5 .

The enzymatic potential of high-density lipoproteins is played a cardioprotective role and protected particles, endothelial cells and

${ }^{1}$ Goldstein J.,Brown M. A Century of Cholesterol and Coronaries: From Plaques to Genesto Statins. Cell. 2017. № 161 (1). P. 161-172. DOI: 10.1016/j.cell.2015.01.036.

2 Lieberman A., Swanson J. High Cholesterol at the Heart of Phagolysosomal Damage. Cell Metabolism. 2018. № 27 (3). P. 487-488. DOI: 10.1016/j.cmet.2018.02.015.

${ }^{3}$ Tall A., Yvan-Charvet L. Cholesterol, inflammation and innate immunity. Nature Reviews Immunology. 2015. № 15. P. 104-106. DOI: 10.1038/nri3793.

4 The Framingham Heart Study and the epidemiology of cardiovascular disease: a historical perspective / S. Mahmood et al. The Lancet. 2014. № 383 (9921). P. 999-1008. DOI: 10.1016/S0140-6736(13)61752-3.

5 Native low-density lipoprotein promotes lipid raft formation in macrophages / J. Song et al. Molecular Medicine Reports. 2016. № 13 (3). P. 2087-2093. DOI: 10.3892/mmr.2016.4781. 
cardiomyocytes from modifications and excessive formation of free radicals with their destructive effects ${ }^{6 ; 7}$. It is necessary to determine the quantitative state of high-density lipoprotein cholesterol simultaneously with the functional state since both low and high concentrations are inversely associated with cardiovascular disease. The approved results were obtained by specialists of large-scale research in Copenhagen. According to the results of the population study of different groups by age and gender, the paradoxical fact of an increase of mortality in groups with extremely high cholesterol content of high-density lipoproteins was confirmed ${ }^{8}$.

Indicators of lipid metabolism, which is also determined by cardiovascular disease, include triacylglycerol's structural changes the composition of lipoprotein particles ${ }^{9}$. Since lipoproteins include proteins other than lipids, the determination of their state identifies their functional activity. The most common modifications are oxidation and structural rearrangement of enzymes on the surface of particles. Pro-oxidation of proteins in the composition of high-density lipoproteins and low-density lipoproteins occurs in the development of many pathological conditions, in particular, in hypertension, heart and kidney diseases ${ }^{10 ; 11}$.

Increased systolic and diastolic pressures occur with the development of many cardiometabolic syndromes. Stable increase in blood pressure, that is, acquired disease - hypertension, according to preliminary estimates, scientists have been diagnosed in half of the population in developed countries $^{12 ; 13}$. In related diseases, such as neurodegenerative, diabetes and

${ }^{6}$ Kontush A. HDL-mediated mechanisms of protection in cardiovascular disease. Cardiovascular Research. 2014. № 103. P. 341-349. DOI: 10.1093/cvr/cvu147.

7 Rader D., Hovingh K. HDL and cardiovascular disease. Lancet. 2014. № 384 (9943). P. 618-625. DOI: 10.1016/S0140-6736(14)61217-4

${ }^{8}$ Extreme high high-density lipoprotein cholesterol is paradoxically associated with high mortality in men and women: two prospective cohort studies / C. Madsen et al. European Heart Journal/ 2017. № 38 (32). P. 2478-2486. DOI: 10.1093/eurheartj/ ehx 163 .

Association analyses of East Asian individuals and trans-ancestry analyses with European individuals reveal new loci associated with cholesterol and triglyceride levels / C. Spracklen et al. Human Molecular Genetics. 2017. № 26 (9). P. 1770-1784. DOI: 10.1093/hmg/ddx062.

${ }^{10}$ High-density lipoprotein efficiently accepts surface but not internally oxidised lipids from oxidised low-density lipoprotein / A. Rasmiena et al. Biochimica et Biophysica Acta. 2016. № 1861 (2). P. 69-77. DOI: 10.1016/j.bbalip.2015.11.002.

${ }^{11}$ Paraoxonase Levels are Correlated with Impaired Aortic Functions in Patients with Chronic Kidney Disease / T. Efe et al. Acta Cardiologica Sinica. 2016. № 32 (1). P. 75-80. DOI: 10.6515/ACS20150429A.

${ }_{12}$ Proteomic diversity of high-density lipoproteins: our emerging understanding of its importance in lipid transport and beyond / A. Shah et al. Journal of Lipid Research.2013. № 54. P. 2575-2585. DOI: 10.1194/jlr.R035725.

${ }^{13}$ Kratzer A., Giral H., Landmesser U. High-density lipoproteins as modulators of endothelial cell functions: alterations in patients with coronary artery disease. Cardiovascular Research. 2014. № 103. P. 350-361. DOI: 10.1093/cvr/cvu139. 
chronic inflammatory processes, it leads to secondary complications and progression of atherosclerosis ${ }^{14}$.

Currently, there is no unified list of prognostic markers of cardiovascular disease, so the study of potential indicators of the development of pathological conditions of the cardiovascular system is necessary and important for their prevention and avoidance of secondary complications ${ }^{15 ; 16 ; 17}$. Also, the full mechanism of the occurrence of primary and secondary cardiometabolic risks is completely unknown. In particular, it is important for patients with kidney diseases with complication which can be caused by changing of lipoprotein oxidative status. Therefore, the aim of our research work is to summarizing investigated data about the qualitative state of high-density lipoproteins by the activity of their associated enzymes, in particular paraoxonase-1 and myeloperoxidase, for arterial hypertension, namely the second type and resistant arterial hypertension, myocardial infarction, chronic heart failure, chronic kidney disease and chronic lung disease.

The venous blood samples were taken from 260 patients (women and men, average age $-18-55$ years): 35 of them with arterial hypertension the second type and 40 with resistant arterial hypertension, 32 with myocardial infarction, 35 with chronic heart failure (patients with the cardiovascular disease treated at National Scientific Center "M.D. Strazhesko Institute of Cardiology"), 85 with chronic kidney disease I-V stage (patients treated at SI Institution of Nephrology NAMS) and 33 with chronic lung disease (patients treated at SO "National institute of phthisiology and pulmonology named after F.G. Yanovsky NAMS of Ukraine"). The control group had consisted of 41 healthy donors of the same age. The informed consent was given by all participants before the procedure of obtaining their blood for research. The protocol of investigating (№ 7, 30.08.2016) was approved by the Commission on Bioethics of SI Institution of Nephrology NAMS. Blood from the cubit al vein had been centrifuged for $15 \mathrm{~min}$ at $1500 \mathrm{~g}$ and treated with serum.

The activity of paraoxonase- 1 is determined by the amount of specific substrate ( $4 \mathrm{mM}$ phenylacetate) used during the biochemical interaction, which is measured at a wavelength of $270 \mathrm{~nm}$ and expressed in $\mathrm{kU} / 1^{18}$.The

${ }^{14}$ Riwanto M., Landmesser U. High-density lipoproteins and endothelial functions: mechanistic insights and alterations in cardiovascular disease. Journal of Lipid Research. 2013. № 54 (12). P. 3227-3243. DOI: 10.1194/jlr.R037762.

${ }^{15}$ Hering D., Trzebski A., Narkiewicz K. Recent advances in thepathophysiology of arterial hypertension: potential implications for clinical practice. Polish Archives of Internal Medicine. 2017. № 127 (3). P. 195-204. DOI: 10.20452/pamw.3971.

${ }^{16}$ Characterization of a novel high-density lipoprotein antioxidant capacity assay and its application to high-density lipoprotein fractions / K. Gaal et al. Clinical Biochemistry. 2013. № 46. P. 825-827. DOI: 10.1016/j.clinbiochem.2013.01.007.

${ }_{17}$ Proteomic Analysis of Human Serum from Patients with Chronic Kidney Disease / Y. Romanova et al. Biomolecules. 2020. № 10. P. 257. DOI: 10.3390/biom10020257.

${ }_{18}$ Reduced Paraoxonase 1 Activity as a Marker for Severe Coronary Artery Disease / C. Zhou et al. Disease Markers. 2013. № 35(2). P. 97-103. DOI: 10.1155/2013/816189. 
activity of myeloperoxidase is determined by the oxidation of the chromogenic substrate $(3,8 \mathrm{mM}$ 3,3'-dimethoxybenzidine) during the biochemical interaction, which is measured at a wavelength of $460 \mathrm{~nm}$ during $8 \mathrm{~min}$ and expressed in conventional units per litre (c.U / 1) ${ }^{19}$. Statistical analysis is provided by Shapiro-Wilk normality test, criteria of Newman - Keuls method $(\mathrm{p}<0,05)$. The difference between the group's indexes was significant $(\mathrm{p}<0,05)$.

\section{Characterization of the qualitative state of lipoproteins}

Lipoproteins are complexes formed by proteins and lipids to transport substances through the bloodstream. The functional activity of lipoproteins can predict by the number of proteins in the composition and the activity of lipoprotein-associated enzymes. The enzymes play a key role in many receptor interactions, catalysis of biochemical reactions, and a specific set of polar and nonpolar lipids forms a hydrophilic outer layer and a hydrophobic chamber $^{20 ; 21}$.

One of the most important enzymes in the composition of high-density lipoproteins is paraoxonase, namely, the first isoform (paraoxonase-1). Paraoxonase-1 is a multifunctional enzyme. It promotes regression of atherosclerotic plaques by exhibiting antiatherogenic properties and normalizes the work of cardiomyocytes as a cardioprotectiveenzyme ${ }^{22 ; 23 ; 24}$. Paraoxonase has hydrolase, arylesterase and lactonase activities. Enzyme conducts esterase hydrolysis of oxidized lipids which can lead to a decrease in the size of atherosclerotic plaques ${ }^{25}$.

Paraoxonase-1 together with myeloperoxidase formed an associated complex. Both enzymes partially inhibit each other, which reduces their affinity for high-density lipoprotein particles. The substrate for

${ }^{19}$ Новые подходы к определению концентрации и пероксидазной активности миелопероксидазы в плазме крови человека / И. Горудко и др. Биоорганическая химия. 2009. № 35 (5). С. 629-39.

${ }^{20}$ Roles of inflammation, oxidative stress, and vascular dysfunction in hypertension / Q. Dinh et al. BioMed Research International. 2014. № 132 (4) : 406-28. DOI: $10.1155 / 2014 / 406960$.

${ }^{21}$ Kratzer A., Giral H., Landmesser U. High-density lipoproteins as modulators of endothelial cell functions: alterations in patients with coronary artery disease. Cardiovascular Research. 2014. № 103. P. 350-361. DOI: 10.1093/cvr/cvu139.

${ }^{22}$ High-density lipoprotein-associated paraoxonase-1 activity for prediction of adverse outcomes in outpatients with chronic heart failure / M. Hammadah et al. European Journal of Heart Failure. 2017. № 19 (6). P. 748-755. DOI: 10.1002/ejhf.777.

${ }^{23}$ High-density lipoprotein modulates thrombosis by preventing von Willebrand factor self-association and subsequent platelet adhesion / D. Chung et al. Blood. 2016. № 127 (5). P. 637-645. DOI: 10.1182/blood-2014-09-599530.

${ }^{24}$ Коваленко В., Кучменко О., Мхітарян Л. Молекулярно-генетичні особливості функціонування параоксонази та ії значення в розвитку серцево-судинної патології. Украӥнський кардіологічний журнал. 2014. № 5. С. 105-116.

${ }_{25}$ Remaley A., Norata G., Catapano A. Novel concepts in HDL pharmacology. Cardiovascular Research. 2014. № 103. P. 423-428. DOI: 10.1093/cvr/cvu141. 
myeloperoxidase is hydrogen peroxide. The enzyme has a peroxidase activity and also able to carry out two-electron oxidation of halogens and pseudohalogens.

Peroxidase activity is increased in infectious and inflammatory processes, which, in turn, induces the processes of free radical lipid and nonradical oxidation and the appearance of reactive oxygen species ${ }^{26 ; 27}$.

Lipoproteins are multifunctional transport complexes that are evolutionarily adapted for the transport of lipids and other fat-soluble components in the bloodstream. The state of high-density lipoproteins reflectsparaoxonase-1 and myeloperoxidase in their content. Paraoxonase protects particles from modification and carries out esterase hydrolysis of oxidized lipids.

\section{The qualitative state of lipoproteins in cardiovascular diseases}

The low-density lipoproteins play a key role in atherosclerotic changes, among all classes of lipoproteins, that lead to chronic and acute cardiovascular disease. The numerous modifications of particles can undergo during their metabolism. These include low-density lipoprotein oxidation, malondialdehyde formation, glycosylation, carbonylation, and desialiation ${ }^{28 ; 29}$. Only oxidized lowdensity lipoproteins are capable of accumulating in macrophages and deposited in the vascular walls. The oxidation reaction can be induced by reactive oxygen species, metal ions (iron and copper), enzymes related to the metabolic transformations of lipoproteins of different fractions, and other lipoproteinassociated enzymes. Metal ions are involved in the oxidation of lipid components, while enzymes (lipoxygenases and myeloperoxidase) - in proteins $^{30}$.

The metabolism of high-density lipoproteins provides a normal physiological and morphological state of the body, removing cholesterol from cells and excreting it. Endothelial cells are the first link that suffers from the disruption of lipoprotein's metabolism. Cholesterol-overloaded macrophages are incapable of being transported to the liver and penetrating

\footnotetext{
${ }^{26}$ Myeloperoxidase levels predicts angiographic severitv of coronarv arterv disease in patients with chronic stable angina / M. Baseri et al. Advanced Biomedical Research. 2014. № 3. P. 137. DOI: 10.4103/2277-9175.135155.

The roles of myeloperoxidase in coronary artery disease and its potential implication in plaque rupture / N. Teng et al. Redox Report. 2016. № 22 (2). P. 51-73. DOI: $10.1080 / 13510002.2016$.

${ }^{28}$ Lipoprotein redox status evaluation as a marker of cardiovascular disease risk in patients with inflammatory disease / A. Ungurianu et al. Molecular Medicine Reports. 2017. № 15. P. 256-262. DOI: 10.3892/mmr.2016.5972.

Phillips M. New insights into the determination of HDL structure by apolipoproteins. Journal of Lipid Research. 2012. № 54. P. 2034-2048. DOI: 10.1194/jlr.R034025.

${ }^{30}$ Murakami T., Okamoto H., Kim H. Structural and functional changes in highdensity lipoprotein induced by chemical modification. Biomaterials Science. 2015. № 3. P. 712-715. DOI: 10.1039/C4BM00402G.
} 
the subendothelial layer, contributing to the formation of plaques in the vessels. Dysfunction of high-density lipoproteins is associated with changes in their proteome. Modifications of the molecules may be oxidation, excess reactive oxygen species, phosphorylation, dephosphorylation of terminal amino acids, and protein displacement of the acute phase of inflammation $^{31,32}$. Myeloperoxidase can provoke the destruction of the surface of the plaquelayers in vitro, which became unstable, and, in turn, leads to the formation of blood clots ${ }^{33}$.

The link between the qualitative state of lipoproteins and the development of cardiovascular disease in historical retrospective has not always been evaluated as interdependent changes. To date, a clear relationship has been established between lipid metabolism and cardiometabolic risks. For the first time, researchers from the Framingham group drew attention to this. At the time, they made sensational conclusions that hypertension, together with impaired lipid metabolism, leads to the emergence and exacerbation of cardiovascular pathologies ${ }^{34 ; 35}$.

In cardiovascular diseases, including hypertension, high-density lipoproteins lose their cardioprotective properties and structural integrity ${ }^{36}$.

Under normal metabolism, high-density lipoproteins reduce platelet aggregation, prevent accumulation in the vascular endothelium of cholesterol. Particles protect also from oxidation themselves, regulate glucose metabolism, vascular constriction and have cytoprotective effects on endothelial cells ${ }^{37}$.

According to our research, myeloperoxidase activity in patients with resistant hypertension was increased twice times and almost three times in patients with second-degree arterial hypertension in contrast with conditionally healthy donors (Table 1.1). Patients with myocardial infarction characterized the higher level of enzyme's activity in contrast with donors but this may be explained by the compensatory mechanisms that are triggered after acute cardiometabolic events.

${ }^{31}$ Clinical classification of plaque morphology in coronary disease / F. Otsuka et al. Nature Reviews Cardiology. 2014. № 11 (7). P. 379-389. DOI: 10.1038/nrcardio.2014.62.

${ }^{32}$ Gordon S., Remaley A. High-density lipoproteins are modulators of protease activity: Implications in inflammation, complement activation, and at hero thrombosis. Atherosclerosis. 2017. № 259. P. 104-113. DOI: 10.1016/j.atherosclerosis.2016.11.015.

${ }^{33}$ Rader D. Spotlight on HDL biology: new insights in metabolism, function, and translation. Cardiovascular Research. 2014. № 103. P. 337-340. DOI: 10.1093/cvr/cvu164.

${ }^{34}$ Eckardstein A., Widmann C. High-density lipoprotein, beta cells, and diabetes. Cardiovascular Research. 2014. № 103. P. 384-394. DOI: 10.1093/cvr/cvu143.

35 Hvpertension as an autoimmune and inflammatory disease / Y. Solak et al. Hypertension Research. 2016. № 39 (8). P. 567-573. DOI: 10.1038/hr.2016.35.

${ }^{36}$ Van der Stoep M., Korporaal S. , Van Eck M. High-density lipoprotein as a modulator of platelet and coagulation responses. Cardiovascular Research. 2014. № 103 (3). P. 362-371. DOI: 10.1093/cvr/cvu137.

${ }^{37} \mathrm{HDL}$ in innate and adaptive immunity / A. Catapalo et al. Cardiovascular Research. 2014. № 103. P. 372-383. DOI: 10.1093/cvr/cvu150. 
The activity of paraoxonase- 1 decreased vice versa in all groups with heart diseases: on 51\% patients with second-degreearterial hypertension; on $60,4 \%$ patients with resistant hypertension; on $79,5 \%$ patients with myocardial infarction; on $61,6 \%$ patients with chronic heart failure.

Table 1

\section{Indicators of activity of enzymes associated} with high-density lipoproteins

\begin{tabular}{|c|c|c|c|c|c|}
\hline Groups & Practically & $\begin{array}{c}\text { Patients with } \\
\text { second- } \\
\text { degree } \\
\text { arterial } \\
\text { hypalthy }\end{array}$ & $\begin{array}{c}\text { Patients with } \\
\text { resistant } \\
\text { hypertension }\end{array}$ & $\begin{array}{c}\text { Patients } \\
\text { with } \\
\text { myocardial } \\
\text { infarction }\end{array}$ & $\begin{array}{c}\text { Patients } \\
\text { with } \\
\text { chronic } \\
\text { heart } \\
\text { failure }\end{array}$ \\
\hline $\begin{array}{c}\text { Myeloperoxidase } \\
\text { (c.U / 1) }\end{array}$ & $2,2 \pm 0,11$ & $6,1 \pm 0,18$ & $3,9 \pm 0,21$ & $3,5 \pm 0,17$ & $3,6 \pm 0,4$ \\
\hline $\begin{array}{c}\text { Paraoxonase-1 } \\
\text { (kU / 1) }\end{array}$ & $5,65 \pm 0,2$ & $2,76 \pm 0,13$ & $2,24 \pm 0,09$ & $\begin{array}{c}2,16 \pm \\
0,15\end{array}$ & $\begin{array}{c}2,17 \pm \\
0,19\end{array}$ \\
\hline
\end{tabular}

Increased myeloperoxidase activity and decreased paraoxonase-1 occurred in myocardial infarction, hypertension (second degree and resistant) of patients compared to controls. Patients with chronic heart failure demonstrated the highest value. The ratio between the two enzymes was used to unify the changes in the oxidative state of high-density lipoproteins. This index was 0,389 in practically healthy donors, 2,21 in patients with second-degree arterial hypertension, 1,74 in patients with resistant hypertension, 1,65 in patients with chronic heart failure and 1,6 in patients with myocardial infarction. Thus, the activity of enzymes in the composition of high-density lipoproteins reflects their functional status and indicates pathological changes in the body.

\section{The role of high-density lipoprotein in the pathogenesis of chronic lungs and kidney disease}

The pathogenesis of the respiratory disease is accompanied by metabolic changes not only of lung cells but also of transport molecules, including high-density lipoproteins. Bronchitis, both chronic and non-chronic, is an inflammatory disease of the mucous membrane of the bronchi. This pathological condition is accompanied, as a rule, by coughing, increased sputum production and alteration of its physicochemical properties. In chronic bronchitis, the cough lasts for more than four weeks a year and the frequency of exacerbations and their course are of greatest concern to patients $^{38}$.

38 A Role for Low-Density Lipoprotein receptor-related Protein 1 in the Cellular Uptake of Tissue Plasminogen Activator in the Lungs / S. Lin et al. Pharmaceutical Research. 2016. № 33. P. 72-82. DOI: 10.1007/s11095-015-1763-6. 
The concept the chronic obstructive pulmonary disease includes diseases such as chronic bronchitis and emphysema. Pathological conditions lead to degenerative changes in the tissues of the respiratory tract, deterioration of the morphofunctional state of the alveoli and a decrease in the total volume of the lungs. The gene polymorphism of apoM in European and African populations leads to chronic obstructive pulmonary disease, especially those members of the population are smokers ${ }^{39}$.

The inflammatory process, which is locally concentrated in the lungs, reflects on the general state of the human body. Firstly, oxygen metabolism and carbon dioxide removal from the alveoli are impaired. Secondly, the number of antigens to which the body's modified cells and the etiological objects of bacterial or viral origin that are inducers of this condition in crease. Third, the intensive flow of lipid and protein peroxidation begins overtime, which exacerbates pathological changes in the links associated with the regulation of the metabolism of all cells of the body. This changing is reflected in the state of the lipoproteins as evidenced by the $65 \%$ increase in the peroxide modification index of the low and high-density lipoproteins in chronic bronchitis. Oxidation of the N-terminal region of high-density lipoproteins may give them the ability to become antigenic, promote autoimmune processes and fixing their potential (quantity and activity) ${ }^{40}$. The most characteristic functional enzymes studied in pulmonary pathological conditions of different a etiology are myeloperoxidase, superoxide dismutase and catalase. The direct relationship between the state of high-density lipoproteins and the course of chronic obstructive pulmonary disease opens new horizons in this research area ${ }^{41}$.

Dysfunction of high-density lipoproteins is associated with changes in their proteome. Modifications of the molecules may be oxidation, excess reactive oxygen species, phosphorylation, dephosphorylation of terminal amino acids, and protein displacement of the acute phase of inflammation. Nitric oxide is a key mediator of the respiratory system. Its secretion by endothelial cells inhibits platelet adhesion and aggregation and acts as a vasodilator, that is, it dilates arterioles and arteries, thus regulating vascular resistance ${ }^{42}$.

${ }^{39}$ Characterisation of exacerbations of chronic bronchitis and COPD in Europe: the GIANT study / M. Miravitlles et al. Therapeutic Advances in Respiratory Disease. 2009. № 3. P. 267-277. DOI: 10.1177/1753465809352791.

Активність ліпопротеїн-асоційованих ензимів параоксонази-1 та мієлопероксидази у пацієнтів із хронічною хворобою нирок / В. Васильченко та ін. Український журнал медицини, біологї та спорту. 2019. Т. 4. № 6 (22). С. 321-329. DOI: 10.26693/jmbs04.06.321.

${ }_{41}$ Emerging role of high-density lipoproteins as a player in the immune system / G. Norataa et al. Atherosclerosis. 2012. № 220. P. 11-21. DOI: 10.1016/j.atherosclerosis.2011.06.045.

42 Effect of Oxidation on the Structure of Human Low- and High-Density Lipoproteins / C. Oliveira et al. Biophysical Journal. 2013. № 106. P. 2595-2605. DOI: 10.1016/j.bpj.2014.04.049. 
Reduced activity of paraoxonase-1 leads to the increased manifestation of oxidative stress in the body and is involved in the development of many multifactorial diseases. The paraoxonase- 1 is capable of hydrolyzing lipid peroxides and it promotes the elimination and mediated transport of oxidized low-density lipoprotein; inhibition of cholesterol biosynthesis. Reduced paraoxonase activity may undertake decreased high-density lipoproteins antioxidant capacity in hemodialyzed uremic patients, and, as a result, evaluate the risk of atherosclerosis developing ${ }^{43}$.

The high-density lipoproteins particles are highly heterogeneous and, under chronic kidney disease, may alter their properties, resulting in increased cardiovascular risk. Epidemiological and clinical studies have shown that cardiovascular disease is the major cause of morbidity and mortality among patients with chronic kidney disease. Therefore, damage to large arteries is one of the contributing factors to increased cardiovascular morbidity and mortality of renal patients ${ }^{44}$. The altered high-density lipoproteins subclasses distribution, changed paraoxonase-1 activities on different high-density lipoproteins subclasses as well as diminished antioxidative protection could be important factors in atherosclerosis development in chronic kidney disease and with last-stage renal disease on dialysis patients ${ }^{45 ; 46}$.

The results of biochemical studies have shown that patients with chronic bronchitis and chronic kidney disease have an intensification of oxidative reactions and a decrease in the activity of paraoxonase-1, which can induce oxidative stress. Reduction in the activity of paraoxonase- 1 for chronic bronchitis occurs by $66 \%$, and for chronic kidney disease by $50-70 \%$ (Table 2 ).

The activity of paraoxonase decreases in both pathologies, and myeloperoxidase, on the contrary, increases according to our research data (Table 2). An increase in myeloperoxidase activity for chronic kidney disease is observed by $40-80 \%$, and for chronic bronchitis - three times.

The chronic kidney disease and chronic bronchitis caused the changing in the activity of enzymes in high-density lipoproteins to contain which can admonish about cardiovascular events.

43 Phillips M. New insights into the determination of HDL structure by apolipoproteins. Journal of Lipid Research. 2013. № 54. P. 2034-2048. DOI: 10.1194/jlr.R034025.

${ }^{44}$ Paraoxonase Levels are Correlated with Impaired Aortic Functions in Patients with Chronic Kidney Disease / T. Efe et al. Acta Cardiologica Sinica. 2016. № 32 (1). P. 75-80. DOI: 10.6515/ACS20150429A.

45 The Role and Function of HDL in Patients with Chronic Kidnev Disease and the Risk of Cardiovascular Disease / J. Rysz et al. International Journal of Molecular Sciences. 2020. № 21. P. 601. DOI: 10.3390/ijms21020601.

${ }^{46}$ The Role and Function of HDL in Patients with Chronic Kidney Disease and the Risk of Cardiovascular Disease / J. Rysz et al. International Journal of Molecular Sciences. 2020. № 21. P. 601. DOI: 10.3390/ijms21020601. 
Indicators of activity of enzymes associated with high-density lipoproteins

\begin{tabular}{|c|c|c|c|c|c|}
\hline Groups & \multirow{2}{*}{$\begin{array}{l}\text { Practically } \\
\text { healthy }\end{array}$} & \multirow{2}{*}{$\begin{array}{l}\text { Patients with } \\
\text { chronic } \\
\text { bronchitis }\end{array}$} & \multicolumn{3}{|c|}{ Patients with chronic kidney disease } \\
\hline Indicators & & & I-II stage & III-IV stage & V stage \\
\hline $\begin{array}{c}\text { Myeloperoxidase } \\
\text { (c.U / l) }\end{array}$ & $2,2 \pm 0,11$ & $8,6 \pm 0,3$ & $3,24 \pm 0,4$ & $2,53 \pm 0,32$ & $2,45 \pm 0,15$ \\
\hline $\begin{array}{c}\text { Paraoxonase-1 } \\
(\mathrm{kU} / \mathrm{l})\end{array}$ & $5,65 \pm 0,2$ & $1,92 \pm 0,1$ & $2,2 \pm 0,28$ & $2,3 \pm 0,16$ & $4,7 \pm 0,75$ \\
\hline
\end{tabular}

\section{CONCLUSIONS}

Lipoproteins are multifunctional transport complexes for the transport of lipids and other fat-soluble components in the bloodstream. The activity of lipoprotein-related enzymes is the most informative data about their functional state. Paraoxonase-1 and myeloperoxidase protect high-density lipoproteins from modification and carry out esterase hydrolysis of oxidized lipids. Myeloperoxidase reduces hydrogen peroxide and, in nimiety of their reactions, inhibits the activity of paraoxonase-1. Therefore, enzymes act as antagonists for each other.

A decrease in the activity of paraoxonase- 1 and an increase in the activity of myeloperoxidase are observed in both types of hypertension and myocardial infarction.

Thus, the cardioprotective potential of high-density lipoproteins is reduced and the processes of free radical oxidation induced by myeloperoxidase as a cationic protein, which binds to the cell membrane and is capable of causing tissue damage in inflammatory cells, are activated.

The activity of enzymes in the composition of high-density lipoproteins varies also equally in chronic kidney disease and chronic bronchitis: the activity of paraoxonase-1 is reduced, and myeloperoxidase is increased.

Reduction of arylesterase activity of paraoxonase-1 leads to the loss of its inherent antioxidant and antiatherogenic properties. Since the enzyme is involved in the metabolism of high-density lipoproteins and protects them from modification, its activity is reduced during the excessive oxidation of lipoprotein particles in chronic kidney and pulmonary diseases. The decreased activity of paraoxonase and increase activity of myeloperoxidase can be the basis for the development and progression of cardiovascular pathologies in a patient with renal and pulmonary diseases.

Consequently, the metabolism of lipoproteins is one of the links which change cardiovascular, renal and pulmonary diseases, so their components can serve them adequate prognostic markers. Since cardiovascular pathologies are the most severe and susceptible to drug correction, this is the initial stage of dysfunction development, so these markers can increase levels of diagnosis and prevent the development of complications. 


\section{SUMMARY}

Lipoproteins are multifunctional transport complexes that are evolutionarily adapted for the transport of lipids and other fat-soluble components in the bloodstream. The most informative data on functional capacity is the activity of lipoprotein-related enzymes. For high-density lipoproteins, it is paraoxonase and myeloperoxidase. Isoforms 1 and 3 paraoxonase protect lipoproteins from modification and carry out esterase hydrolysis of oxidized lipids. And myeloperoxidase inhibits the activity of paraoxonase, that is, they act as antagonists for each other. The state of lipoproteins can be determined by different parameters. Functional or qualitative status is determined by the activity of enzymes that are part of lipoproteins because the presence of the enzyme does not guarantee the fulfilment of its direct functions. Therefore, the aim of our research work is to summarizing investigated data about the qualitative state of high-density lipoproteins by the activity of their associated enzymes, in particular paraoxonase-1 and myeloperoxidase, for arterial hypertension, namely the second type and resistant arterial hypertension, myocardial infarction, chronic heart failure, chronic kidney disease and chronic lung disease. The venous blood samples were taken from 260 patients (women and men, age 18-55 years): 142 patients with the cardiovascular disease treated at National Scientific Center "M.D. Strazhesko Institute of Cardiology", 85 with chronic kidney disease I-V stage treated at SI Institution of Nephrology NAMS and 33 with chronic lung disease treated at SO "National institute of phthisiology and pulmonology named after F.G. Yanovsky NAMS of Ukraine". The control group had consisted of 41 healthy donors of the same age. The activity of paraoxonase- 1 is determined by the amount of phenylacetate used during the biochemical interaction. The activity of myeloperoxidase is determined by the oxidation of the chromogenic substrate during the biochemical interaction. The activity of paraoxonase significantly decreases in all pathologies, and myeloperoxidase, on the contrary, noticeably increases according to our research data; in renal and pulmonary diseases decrease the activity of paraoxonase and increase activity of myeloperoxidase can be the basis for the development and progression of cardiovascular pathologies.

\section{REFERENCES}

1. Goldstein J., Brown M. A Century of Cholesterol and Coronaries: From Plaques to Genesto Statins. Cell. 2017. № 161 (1). P. 161-172. DOI: 10.1016/j.cell.2015.01.036.

2. Lieberman A., Swanson J. High Cholesterol at the Heart of Phagolysosomal Damage. Cell Metabolism. 2018. № 27 (3). P. 487-488. DOI: 10.1016/j.cmet.2018.02.015. 
3. Tall A., Yvan-Charvet L. Cholesterol, inflammation and innate immunity. Nature Reviews Immunology. 2015. № 15. P. 104-116. DOI: 10.1038/nri3793.

4. The Framingham Heart Study and the epidemiology of cardiovascular disease: a historical perspective / S. Mahmood et al. The Lancet. 2014. № 383 (9921). P. 999-1008. DOI: 10.1016/S0140-6736(13)61752-3.

5. Native low-density lipoprotein promotes lipid raft formation in macrophages / J. Song et al. Molecular Medicine Reports. 2016. № 13 (3). P. 2087-2093. DOI: 10.3892/mmr.2016.4781.

6. Kontush A. HDL-mediated mechanisms of protection in cardiovascular disease. Cardiovascular Research. 2014. № 103. P. 341-349. DOI: $10.1093 / \mathrm{cvr} / \mathrm{cvu} 147$.

7. Rader D., Hovingh K. HDL and cardiovascular disease. Lancet. 2014. № 384 (9943). P. 618-625. DOI: 10.1016/S0140-6736(14)61217-4.

8. Extreme high high-density lipoprotein cholesterol is paradoxically associated with high mortality in men and women: two prospective cohort studies / C. Madsen et al. European Heart Journal. 2017. № 38 (32). P. 2478-2486. DOI: 10.1093/eurheartj/ehx163.

9. Association analyses of East Asian individuals and trans-ancestry analyses with European individuals reveal new loci associated with cholesterol and triglyceride levels / C. Spracklen et al. Human Molecular Genetics. 2017. № 26 (9). P. 1770-1784. DOI: 10.1093/hmg/ddx062.

10. High-density lipoprotein efficiently accepts surface but not internallyoxidised lipids from oxidised low-density lipoprotein / A. Rasmiena et al. Biochimica et Biophysica Acta. 2016. № 1861 (2). P. 69-77. DOI: 10.1016/j.bbalip.2015.11.002.

11. Paraoxonase Levels are Correlated with Impaired Aortic Functions in Patients with Chronic Kidney Disease / T. Efe et al. Acta Cardiologica Sinica. 2016. № 32 (1). P. 75-80. DOI: 10.6515/ACS20150429A.

12. Proteomic diversity of high-density lipoproteins: our emerging understanding of its importance in lipid transport and beyond /A. Shah et al. Journal of Lipid Research. 2013. № 54. P. 2575-2585. DOI: 10.1194/jlr.R035725.

13. Kratzer A., Giral H., Landmesser U. High-density lipoproteins as modulators of endothelial cell functions: alterations in patients with coronary artery disease. Cardiovascular Research. 2014. № 103. P. 350-361. DOI: $10.1093 / \mathrm{cvr} / \mathrm{cvu} 139$.

14. Riwanto M., Landmesser U. High-density lipoproteins and endothelial functions: mechanistic insights and alterations in cardiovascular disease. Journal of Lipid Research. 2013. № 54 (12). P. 3227-3243. DOI: 10.1194/jlr.R037762.

15. Hering D., Trzebski A., Narkiewicz K. Recent advances in the pathophysiology of arterial hypertension: potential implications for clinical 
practice. Polish Archives of Internal Medicine. 2017. № 127 (3). P. 195-204. DOI: 10.20452/pamw.3971.

16. Characterization of a novel high-density lipoprotein antioxidant capacity assay and its application to high-density lipoprotein fractions / K. Gaal et al. Clinical Biochemistry. 2013. № 46. P. 825-827. DOI: 10.1016/j.clinbiochem.2013.01.007.

17. Proteomic Analysis of Human Serum from Patients with Chronic Kidney Disease /Y. Romanova et al. Biomolecules. 2020. № 10. P. 257. DOI: 10.3390/biom10020257.

18. Reduced Paraoxonase 1 Activity as a Marker for Severe Coronary Artery Disease / C. Zhou et al. Disease Markers. 2013. № 35 (2). P. 97-103. DOI: $10.1155 / 2013 / 816189$.

19. Новые подходы к определению концентрации и пероксидазной активности миелопероксидазы в плазме крови человека / И. Горудко и др. Биоорганическая химия. 2009. № 35 (5). С. 629-39.

20. Roles of inflammation, oxidative stress, and vascular dysfunction in hypertension / Q. Dinh. BioMed Research International. 2014. № 132 (4) : 406-28. DOI: 10.1155/2014/406960.

21. Kratzer A., Giral H., Landmesser U. High-density lipoproteins as modulators of endothelial cell functions: alterations in patients with coronary artery disease. Cardiovascular Research. 2014. № 103. P. 350-361. DOI: $10.1093 / \mathrm{cvr} / \mathrm{cvu} 139$.

22. High-density lipoprotein-associated paraoxonase-1 activity for prediction of adverse outcomes in outpatients with chronic heart failure / M. Hammadah et al. European Journal of Heart Failure. 2017. № 19 (6). P. 748-55. DOI: 10.1002/ejhf.777.

23. High-density lipoprotein modulates thrombosis by preventing von Willebrand factor self-association and subsequent platelet adhesion / D. Chung et al. Blood. 2016. № 127(5). P. 637-45. DOI: 10.1182/blood2014-09-599530.

24. Коваленко В., Кучменко О., Мхітарян Л. Молекулярно-генетичні особливості функціонування параоксонази та ii значення в розвитку серцево-судинної патології. Украӥнський кардіологічний журнал. 2014. № 5. C. $105-16$.

25. Remaley A., Norata G., Catapano A. Novel concepts in HDL pharmacology. Cardiovascular Research. 2014 № 103. P. 423-28. DOI: $10.1093 / \mathrm{cvr} / \mathrm{cvu} 141$.

26. Myeloperoxidase levels predicts angiographic severity of coronary artery disease in patients with chronic stable angina / M. Baseri et al. Advanced Biomedical Research. 2014. № 3. P. 137. DOI: 10.4103/22779175.135155.

27. The roles of myeloperoxidase in coronary artery disease and its potential implication in plaque rupture / N. Teng et al. Redox Report. 2016. № 22 (2). P. 51-73. DOI: 10.1080/13510002.2016. 
28. Lipoprotein redox status evaluation as a marker of cardiovascular disease risk in patients with inflammatory disease / A. Ungurianu et al. Molecular Medicine Reports. 2017. № 15. P. 256-262. DOI: 10.3892/mmr.2016.5972.

29. Phillips M. New insights into the determination of HDL structure by a polipoproteins. Journal of Lipid Research. 2012. № 54. P. 2034-2048. DOI: 10.1194/jlr.R034025.

30. Murakami T., Okamoto H., Kim H. Structural and functional changes in high-density lipoprotein induced by chemical modification. Biomaterials Science. 2015. № 3. P. 712-715. DOI: 10.1039/C4BM00402G.

31. Clinical classification of plaque morphology in coronary disease / F. Otsuka et al. Nature Reviews Cardiology. 2014. № 11 (7). P. 379-89. DOI: $10.1038 /$ nrcardio.2014.62.

32. Gordon S., Remaley A. High-density lipoproteins are modulators of protease activity: Implications in inflammation, complement activation, and atherothrombosis. Atherosclerosis. 2017. № 259. P. 104-113. DOI: 10.1016/j.atherosclerosis.2016.11.015.

33. Rader D. Spotlight on HDL biology: new insights in metabolism, function, and translation. Cardiovascular Research. 2014. № 103. P. 337-340. DOI: org/10.1093/cvr/cvu164.

34. Eckardstein A., Widmann C. High-density lipoprotein, beta cells, and diabetes. Cardiovascular Research. 2014. № 103. P. 384-394. DOI: $10.1093 / \mathrm{cvr} / \mathrm{cvu} 143$.

35. Hypertension as an autoimmune and inflammatory disease / Y. Solak et al. Hypertension Research. 2016. № 39 (8). P. 567-73. DOI: 10.1038/hr.2016.35.

36. Van der Stoep M., Korporaal S., Van Eck M. High-density lipoprotein as a modulator of platelet and coagulation responses. Cardiovascular Research. 2014. № 103 (3). P. 362-371. DOI: $10.1093 / \mathrm{cvr} / \mathrm{cvu} 137$.

37. HDL in innate and adaptive immunity / A. Catapalo et al. Cardiovascular Research. 2014. № 103. P. 372-383. DOI: 10.1093/cvr/cvu150.

38. A Role for Low-Density Lipoprotein receptor-related Protein 1 in the Cellular Uptake of Tissue Plasminogen Activator in the Lungs / S. Lin et al. Pharmaceutical Research. 2016. № 33. P. 72-82. DOI: 10.1007/s11095015-1763-6.

39. Characterisation of exacerbations of chronic bronchitis and COPD in Europe: the GIANT study / M. Miravitlles et al. Therapeutic Advances in Respiratory Disease. 2009. № 3. P. 267-277. DOI: $10.1177 / 1753465809352791$.

40. Активність ліпопротеїн-асоційованих ензимів параоксонази-1 та мієлопероксидази у пацієнтів із хронічною хворобою нирок / 
В. Васильченко. Украӥнський журнал медицини, біологї̈ та спорту. 2019. T. 4. № 6 (22). C. 321-329. DOI: 10.26693/jmbs04.06.321.

41. Emerging role of high-density lipoproteins as a player in the immune system / G. Norataa et al. Atherosclerosis. 2012. № 220. P. 11-21. DOI: 10.1016/j.atherosclerosis.2011.06.045.

42. Effect of Oxidation on the Structure of Human Low- and HighDensity Lipoproteins / C. Oliveira et al. Biophysical Journal. 2013. № 106. P. 2595-2605. DOI: 10.1016/j.bpj.2014.04.049.

43. Phillips M. New insights into the determination of HDL structure by a polipoproteins. Journal of Lipid Research. 2013. № 54. P. 2034-2048. DOI: 10.1194/jlr.R034025.

44. Paraoxonase Levels are Correlated with Impaired Aortic Functions in Patients with Chronic Kidney Disease / T. Efe et al. Acta Cardiologica Sinica. 2016. № 32 (1). P. 75-80. DOI: 10.6515/ACS20150429A.

45. Activity of paraoxonase 1 (PON1) on HDL2 and HDL3 subclasses in renal disease / M. Miljkovic et al. Clinical Biochemistry. 2018. № $60: 52-8$. PMID : 30130521. DOI: 10.1016/j.clinbiochem.2018.08.006.

46. The Role and Function of HDL in Patients with Chronic Kidney Disease and the Risk of Cardiovascular Disease / J. Rysz et al. International Journal of Molecular Sciences. 2020. № 21. P. 601. DOI: 10.3390/ijms21020601.

\section{Information about authors:} Vasylchenko V.S.,

PhD Student of the Department of Biology National University of "Kyiv-Mohyla Academy"

2, Skovorody str., Kyiv, 04070, Ukraine Junior Research Fellow State Institution "Institute of Nephrology of the National Academy of Medical Sciences of Ukraine" 17 V, Dehtiarivska str., Kyiv, 04050, Ukraine

Kuchmenko O. B., Doctor of Biological Sciences, Associate Professor at the Department of Biology Nizhyn Mykola Gogol State University 2, Grafska str., Nizhyn, 16600, Ukraine Department of Biology National University of "Kyiv-Mohyla Academy" 2, Skovorody str., Kyiv, 04070, Ukraine 